\title{
Fonó és Kisgyalán községek népi építészete, az istállók rendeltetésének változása
}

\author{
LANSZKINÉ SZÉLES GABRIELLA és LANSZKI JÓZSEF
}

Kaposvári Egyetem, Természetvédelmi és Környezetgazdálkodási Tanszék, H-7400 Kaposvár, Guba Sándor út 40., e-mail.: lanszkine.gabriella@ke.hu

\begin{abstract}
LANSZKInÉ, Sz. G. \& LANSZKı J.: Folk architecture and changes in function of stables in Fonó and Kisgyalán villages.

Abstract: The aim of this study was to compare the folk architecture of two neighbouring villages in Outer-Somogy; Fonó and Kisgyalán. The prestigious agricultural buildings were built in the 19th century as a result of the change in farm management conditions due to river control and drainage. Field experience proved that the function of stables significantly changed by the 21st century. The stables had residential function in many cases; these barns were quantified in both villages on street basis. In those streets which were established after 1945, barns built were not always finished, their proportion, quality and conversion into house for living were nearly the same in both villages. However, Kisgyalán had an average financial position, while Fonó was a rich village with middle peasants. Consequently, the true-born population of two villages built different quality agricultural buildings and structures. Shed of extremely high standard were found in Fonó, while beautifully crafted corncribs were established in Kisgyalán. The preservation of the buildings is of high interest of the population of both villages.
\end{abstract}

Keywords: folk architecture, agricultural buildings, corncribs, Somogy county

\section{Bevezetés}

A Kapos mentén a 20. században rangos istállós pajták készültek, amelyek egy része még ma is emeli a község épületállományának színvonalát, és az ahhoz értőkben csodálatot kelt legyen az építész vagy parasztgazda. Ezekben az istállókban az állatokkal együtt férfiak is tartózkodtak éjjel is. Hogy mi oknál fogva kerültek ki az istállóba az emberek, ennek magyarázatát a szarvasmarha-tenyésztés tartástechnológiáján keresztül lehet megadni.

A 19-20. század folyamán megváltoztak a szarvasmarha-tenyésztési feltételek, ebből adódóan új épületekre lett szükség. A népi építészet ennek a kihívásnak tökéletesen megfelelt, igazán tiszteletet parancsoló istállók, pajták születtek, két külső-somogyi községben is. Kaposvár vonzáskörzetéhez tartózó Fonóban valamint Kisgyalánban történt az istállókkal kapcsolatos gyüjtés, a községek 17 km-re, illetve 21 km-re fekszenek Kaposvártól. Foglalkoztatott az a kérdés is bennünket, hogy a 21. századra, miképp alakult ezeknek az épületeknek a sorsa.

„...A mi szempontunkból az az épített örökség fontos, amely még anyagi valójában létezik, és amelyet kezelni felelősségünk és feladatunk."1 Ebből az irányelvből kiindulva, készült 300 db-on felüli fotó dokumentációs anyag hogy az épületek jelenlegi állapotát megörökítsék.

1 Kottmayer T. 2003: 7.
„Vitathatatlan, hogy egy utcaképben meghatározó, hogy a közterületről látható portarészek egyöntetüek, vagy nagy változatosságot mutatnak. A hagyományos faluképben a méretek és tömegformák nagymérvü hasonlósága volt jellemző. Ezt erősítette az anyaghasználat egyöntetűsége is." ${ }^{2} A$ fotók hűen tanúsítják ezt a tényt.

\section{Az istállózó szarvasmarha tenyésztés előzményei}

Az a hosszú folyamat, ami életre hívta ezeket a gazdasági épületeket a török kiűzését, valamint a Rákóczi-féle szabadságharcot követően kezdődött. Mindkét falu ekkorra már harmadszor települt újra, de már a jelenlegi helyén. Az indulás hasonlóan kezdődött, Fonóban és Kisgyalánban egyaránt.

„Ennek a területnek a teljesen magyar lakosságú települései ahová több összeírás névanyagának elemzése alapján tudjuk, egyetlen „idegen”, azaz nem magyar népcsoportba tartozó telepes sem érkezett 1720 és 1727 között a következőkbe: Gölle..., Fonó, Boronka, Büssü, Kazsok, Várda, Zimány, Gyalán."3

Magyar jobbágyfaluként indult mindkét helység, a névanyagot áttanulmányozva az ekkor letelepültek utódai azok, akik majd 300 éven keresztül meghatározták a két falu sorsát, előre menetelét, ők alakították ki e falvak arculatát. Az ekkor betelepített német telepesek itt nem alkottak közösséget, így a magukkal hozott marhák, itt nem befolyásolták a fajta összetételt, bár a szomszédos Tolna megyében kitenyésztették később a német telepesek az úgynevezett bonyhádi tájfajtát.

„A tájfajta kialakulásáról alkotott vélemények, kutatási eredmények, a szakirodalom erre utaló írásai és nem utolsó sorban a szájhagyomány megannyi egymástól eltérő megállapítást tárnak elénk.” „Az azonban nem vitatható, hogy a német telepesek - mind a korábbiak, mind a XVIII. század idején ide települtek - szarvasmarha-tenyésztésünk fejlődésére jelentős hatással voltak, de ők azok, akik régi hazájuk állattenyésztésének példája nyomán a tejgazdaság és az istállózott szarvasmarha-tenyésztés alapját megvetették."5

A feltételek a környező magyar falvakban is több szempontból megteremtődtek az istállózó (intenzív) szarvasmarha-tenyésztéshez.

2 Kottmayer T. 2003: 16

3 Szita L. 1993: 28

4 Ettig L. 1999: 20.

5 Bocsor G. 1960: 31. 
„A Kapos szabályozását követő időszakban a földmüvelésnek és az állattenyésztésnek belterjessé válása is jellemző. ...A rétgazdálkodás a dél-külső-somogyi lösztábla déli részén messze északra nyúló völgyeiben is hasonló lehetőséget biztosított, s így vált lehetővé a Kapos-völgy híres állattenyésztésének kialakulása."6

Egy Fonó és Baté közötti peres ügy is utal érdekességként a vízszabályozások korából az akkori viszonyokra. Török Ferenc mérnök által értesülhetünk a szarvasmarha-legeltetésről, de arról is, hogy a fonóiak tulajdonukat bármi áron megvédik. „Itéltetett: Abban tevén a Fel Peres Úr panaszát, hogy az ő Batéi Helysége, és a Tisztelendő áhitatos oskolák Szerzetje Fonói Helységének határa közt, edig berek lévén helyheztetve, melly 1810.-ik esztendőben felmérettetet, és annak közepén huzatott árokkal, nem csak vize lecsapoltatott, de a két Telek közt egyenlő részre fel is osztatott. ...miglen a közelebb elmult Tavasz kezdetével, először a Fonói marha csorda erőhatalommal, azon választó árkon által hajtatott, másodszor ismét Julius Holnapnak 8.kán is ezen hatalmaskodással való behajtás, ujjra megtörtént, melly alkalmatossággal Gál György Úr, a marhákat be hajtatni kivánván, a Fonóiak rettenetes káromkodások közt, és gyilkosi erőszak módon,...és illetlen nevezetekkel tituláltatván, a marhák a Batéi= itató hideg kutnál vissza vetettek, és ekképen békességes birtoka meg háboríttatott." Talán már ekkor sem ok nélkül követték el a birtokháborítást, marháik legelöhöz jutása érdekében a fonóiak, már ekkor is kevés lehetett a legelő. A jobb takarmánnyal való ellátottság érdekében történtek a szántóföld növelését célzó erdőirtások, valamint a lecsapolások.

„A lecsapolási munkálatokat Török Ferenc (17791832) végezte. Török somogyi müködésének ideje alatt részben az ő tervei alapján és vezetésével szabályozták az addig zabolátlan folyókat, mocsarakat csapoltak le. Térképei megrajzolására különös gondot fordított."8 Elkészítette a gyaláni berek térképét is 1823-ban, amely a Nagyberki Levéltárban található. „A legelő és a rét területének csökkenése arra késztette a parasztságot, hogy a régi, rideg marhatartási módról áttérjen az istállózó marhatartásra." $\mathrm{Ez}$ hoszszas folyamat volt, mire 1810-hez viszonyítva arra késztette a kormányzatot, hogy 1894. évi XII. t.c.-ben a legelők további feltörésének gátat szabjon.

Fonó összes mezőgazdasági müvelés alá eső területéhez 1736 katasztrális holdhoz viszonyítva, az 1935-ös statisztikai felmérés adatai szerint, a legelő csupán 51 kat. hold, a közlegelő pedig 13 kat. hold, a rét 114 kat. hold. Kisgyalánban az összes művelt terület 1348 kat. hold a legelő 130 kat. hold a közlegelő 31 kat. hold, a rét pedig 106 kat. hold..$^{10}$ „A szántóföld bősége és a legelő hiánya a Kapos völgyének parasztságát az istállózott marhatartásra és a szántóföldi takarmánytermelésre kényszerítette... A viszonylag kis

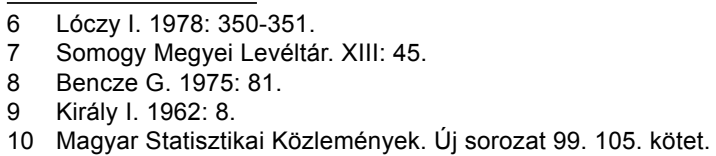

határú kapos-völgyi falvak, amelyek még elég sík terepen is terülnek el, jó üzemi feltételeket biztosítottak az istállózó marhatartásnak."11

\section{Intenzív szarvasmarha tenyésztés}

Fonó és Kisgyalán távolsága csupán $3 \mathrm{~km}$, ezek a községek is a kishatárú falvak közé tartoznak. A 20. század folyamán mindkét falu elindult az istállózó szarvasmarha-tenyésztés útján. Fonó a középparaszti, és gazdagparaszti utat járta be messze kiemelkedett az átlagból, Kisgyalán a kevésbé tehetős átlagos falvak közé tartozott. Ezért a két községet építészeti szempontból összehasonlítva, eltérő minőségű és technikájú épületek, építmények a jellemzőek, látványosabbak még ma is a gazdasági épületek közötti különbségek. „A teljesen istállózott marhatartás példája a kaposvölgyi Fonó község. Ebben községben az idősebb nemzedék nem emlékezik vissza arra, hogy a marhák valaha is legelöre jártak volna"12 A gazdák nem legeltették a marhákat, a sertés konda került csupán kihajtásra az 1940-es évekig. Legeltetés a későbbiek folyamán Kisgyaláni Petőfi Szolgáltató Szövetkezet Fonóban nevelt tenyészüszői számára volt az 1990-es évek közepéig. Kisgyalánban azonban az 1980-as években a gazdák még legeltették üszőiket, teheneiket.

Fonóban tudatos svájci marhaimporttal igyekeztek az 1900-as évek elejétöl felvirágoztatni szarvasmarha-tenyésztésüket. Kisgyalánba is érkezett két darab import tehén. Az igényesebb fajtával a gazdasági épületek iránti igény is változott.

Gazdák, szakemberek, tanítók, szerencsés összefogására volt szükség az előre haladás érdekében, és ha mindez találkozott igen szép eredmények születtek. Ennek a ma még masszívan áló, népi építészet által létrehozott gazdaságiépület-remekek a tanúi.

„Nemcsak birtokjogi, hanem gazdálkodási szempontból is jelentős esemény volt a falu életében, hogy Fonó földesura 1807-ben a Kegyestanítórend lett."13

„Mind nagyobb számban alkalmazott, képzett mezőgazdászaik szaktudása pedig feltétlenül serkentőleg hatott a volt jobbágyok utódaira, a mind önállóbbá váló fonai ${ }^{14}$ gazdákra is. Ez az irányító ráhatás főképp addig tartott, míg a fonai gazdák egy területen felül nem múlták az uradalmat. Míg a szarvasmarha-tenyésztésre nem szakosították magukat oly annyira, hogy kinőttek a helyi keretekből és országos hírnévre tettek szert pompás tenyészállataikkal. Sok kiállításon nyertek díjakat."15

Már az elemi iskolában elültették a gondolatot a gyerekek fejébe, - bár Fonóba ezt már valószínúleg otthonról hozta, - úgyhogy az 1920-40-es évek tankönyveibe beleillesztettek egy olyan „tanmesét”, ami a falusi tizenéves gyerekek okulására szolgált: „Másnap az V.-VI. osztályosok elmentek tanítójukkal a falu

\footnotetext{
11 Király I. 2004: 44-45.

12 Király I. 1962: 25

13 Melhárd Gy. 1906: 46-47

14 A fonai tájnyelvi ejtés, a köznyelvi fonói

15 Rosta F. 1961: 48, 61
} 
legjobb gazdájának, Bozai Imrének az udvarába... Volt azután csodálkozás az istállóban. A nagy ablakok, a fehérre meszelt fal olyan világossá tették, hogy lakásba is beillett volna. A talajt téglával rakták ki, a lovak alatt azonban kipadlózták... Az állatok szőre ragyogott a tisztaságtól. A trágyát naponta háromszor elszedik alóluk. ... Látjátok gyermekek, a jó gazda mindent meglát. Nem hiába mondja a közmondás: A gazda szeme hizlalja a jószágot."16

A kor politikai állásfoglalása is a falusi gyerekek jövőjét illetőleg is ez irányba hatott.

„A kötelező 8 osztályú elemi iskola látogatása miatt a 13-14 éves gyermekek munkája részben kiesne a nemzet munkájából."17 A megfogalmazott cél egyértelmű a falusi gyerek minél előbb kerüljön bele a gazdasági munkák körforgásába. Az Igali járásba tartozó Fonó, méltán érdemelte ki ennek a koncepciónak megfelelve a dicséretet. „Itt szarvasmarha tenyésztéssel számos község foglalkozik már régi idő óta nagy szeretettel, hozzáértéssel, sőt áldozatkészséggel. A sok közül is kiválik Fonó."18 Erröl a híres múltról, ma a gazdasági épületek tanúskodnak. Nemegyszer megtörtént, hogy a falun áthaladó idegenek, azért álltak meg, hogy egy-egy istálló lefényképezésére engedélyt kérjenek.

Fonó falutípusát tekintve szalagtelkes falu, jelenleg négy utcából áll. Az 1720-as években letelepülő elődök oly módon választották meg lakhelyüket, hogy az út és a házak vannak a legmagasabb ponton, az udvar hátrafelé lejt. Az I. katonai felmérésen (1784) már megtalálható első utca, ma a Petőfi utca nevet viseli. A Petőfi utca hosszúra nyúlik, az utca közepe táján lévő templom, elválasztó szerepet is betölt. A templom a mérvadó abban, hogy „arra fö” a temető felé, vagy „arra le” megyünk, amit a falu enyhe déli lejtése határoz meg. A Petőfi utca maradt továbbra is a falu magja, főutcája, ebből nyitottak három új utcát. A Nagyatádi Szabó-féle földreform után a Kossuth utcát, a II. világháború után a Táncsics utcát és a Dózsa utcát létesítették. Mindegyik utcának megvolt, vagy van az egyértelműsítő neve. A Dózsa utcát, Patalomi sornak hívják, mert onnan vezet egy földes út Patalom irányába. A Kossuth utcát, már csak az idősebb generáció hívja „Proletárnak”, akik még emlékeznek rá mikor és kiknek építették itt a házakat. A Táncsics utcát, a Petőfi utcában, Úri negyednek" is hívták a tősgyökeres faluban. Magyarázata, enyhe szomorú élcelődéssel: „Hordócsinnyáló (kádár), is lakott ott akik a maguk szakmájában fölöttünk voltak, szürke tsz-tagoknak." Pedig köztük, a szürke tsz tagok között, voltak, akik annak előtte az Országos Állattenyésztési Kiállításokról hozták haza rendszeresen a díjakat.

\section{Anyag és módszer}

Az adatgyűjtés során, a két községben a gazdasági épületekre vonatkozólag a feltett kérdések a következőek voltak. ${ }^{19}$

1. kérdés. Első tulajdonos-e, a családja építette az istállót, vagy második, esetleg többedik tulajdonos váltás után épült az istálló?

2. kérdés. A két világháború között az istálló épült előbb, vagy a ház? Az1980-as évek után új ház építése esetén, épült-e istálló is?

3. kérdés. A ház vagy az istálló tetőgerinc magassága a nagyobb?

4. kérdés. A ház egybeépült-e az istállóval, vagy különálló?

5. kérdés Van-e állat jelenleg az istállóban, ha nincs mikor volt utoljára?

6. kérdés. Cserép, vagy pala borítja a tetőt? Cserép esetén, mikor volt átforgatva?

7. kérdés. A padozat beton, tégla, vagy döngölt föld?

8. kérdés. Az ajtó egy, kettő, vagy háromosztatú?

9. kérdés. Eredeti állapotában áll-e az istálló?

10. kérdés. Lebontásra került-e az istálló?

11. kérdés. Ha átalakították lakószoba, fürdőszoba, garázs, vagy mühely készült az istállóból?

Ezek közül a kérdések közül nem mindre sikerült választ kapni, összesítés összehasonlításra azokból az adatokból készült, ahol választ adtak a szíves adatközlők minden esetben, minden azonos kérdéscsoportra.

\section{Eredmény és értékelés. Istállók rendeltetésének változása Fonóban és Kisgyalánban}

Fonóban, és Kisgyalánban a kérdésekre adott válaszok adatainak számszerüsítése után, utcánkénti bontásban, magyarázatokkal kiegészítve készült az 1 . és 2. ábra.

Fonóban az utoljára nyitott utca a Dózsa György utca, itt a volt gazdasági cselédek számára osztották ki a házhelyeket az 1940-es évek közepén. A felépült 22 db ház közül, 6 típusterv alapján készült. Ezek közül 3-hoz nem épült istálló, 3-hoz igen. Ezek közül 1 istállót átalakítottak, amelyből konyha készült. $\mathrm{A}$ másik 3 házhoz azért nem épült istálló, mert a teljes család nem a termelőszövetkezetben keresett megélhetést. Eredeti tulajdonos jelenleg három van közülük. Az egyik udvarban a községre nem jellemző módon keresztbe épült a gazdasági épület együttes. Ennek valószínüsíthetően az az oka, hogy dupla a háztelek, tehát hely volt. A tetőgerinc magasság a Dózsa utcában az istállók esetében alacsonyabb, mint a házaké, egy kivételével. A ház és az istálló magasságából levonhatók helyüket megálló általánosítható következtetések. Ahol úgy ítélték meg, hogy nem az állattenyésztés fogja képezni a család

19 A tősgyökeres lakosok szívesen adtak választ kérdéseinkre, beengedtek az udvarukba, segítették a fotózást, visszaemlékezéseikkel élet közelivé tették a gazdasági épületek elkészültének előzményeit, használatukat. A német tulajdonosok ritkán tartózkodnak fonói házaikban, így a szomszédok segítségét kértük több esetben a kérdések feltevésekor. 


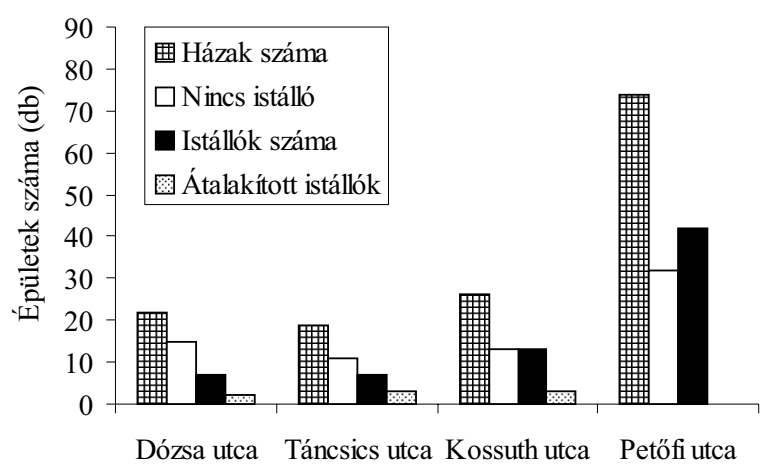

1. ábra. Fonó lakóházainak, istállóinak, valamint az átalakítások utcánkénti alakulásának száma

Table 1: Numbers of the detached houses and sheds of Fonó after the transformátion street by street

megélhetését, ott nem kerekedett felül az istálló magassága a ház fölibe. Az 1920-40 között egyvégtében épült házak esetén egymagasságú a két vizsgált épület típus, az akkori gazdák nem törekedtek arra, hogy a ház fensőbbségét hirdessék. Ahol eleve a ház is vertfalú, ott istálló sem épült a Dózsa utcában. Az utcában a típusházakon kívül meglévő 16 ház közül, 4-hez épült istálló. Mivel a Dózsa utcában nem istállós-pajták épültek, így eredetileg több helyen készült góré, azonban ezek már egy eset kivételével nem a tetszetős lécezett górék, hanem az ácsmester költségeit megspórolandó, esetenként házilag készült, szabálytalan dúcokon álló, dróthálóval körbekerített, kátránypapírral fedett építmények voltak. Jelen esetben ezek közül a górék közül egy áll. A többi összeeszkábált funkcióját vesztett górékat lebontották, mondván ne rontsa az udvar összképét. Az ácsmester által készített, míves kivitelü górékat, ha nem is használják rendeltetésszerüen, akkor sem vinne rá a lélek senkit, hogy lebontsa. Az istállók itt az 1950-60-as évek között épültek. Mind a 7 esetben kisebb, körülbelül $30 \mathrm{~m}^{2}$ alapterületűek, 70\%-kal kisebbek, mint a falu magjában található istállók, de aki tehette díszítettségében követte a nagygazdák által az 1920-as évek végén felállított értékrend által megkövetelt stílus irányzatot. Ebben az utcában már másodlagos szerepet töltött be az istálló, munkahely mellett csupán kiegészítő jövedelemszerzés lehetett a cél. Míg az 1930-40-es években a falu nagygazdái által épült $100 \mathrm{~m}^{2}$ alapterületü istállók, a hozzájuk tartozó tárolókkal, a család teljes megélhetését kellett, hogy biztosítsák.

Az 1990-es években 3 ház épült a Dózsa utcában, az ok, hogy erre az utcára esett a választás, ebben az utcában voltak, és vannak üresen álló házhelyek. A három ház megépültekor fel sem vetődött a gondolat, hogy istállót építsenek hozzá.

A Táncsics utca 19 házból áll. Az egyik 1980-ban épült ház után még elkészült az istálló, ahol még közel egy évtizedig foglalkoztak szarvasmarha-tenyésztéssel. A másik szintén az 1980-as években épült ház

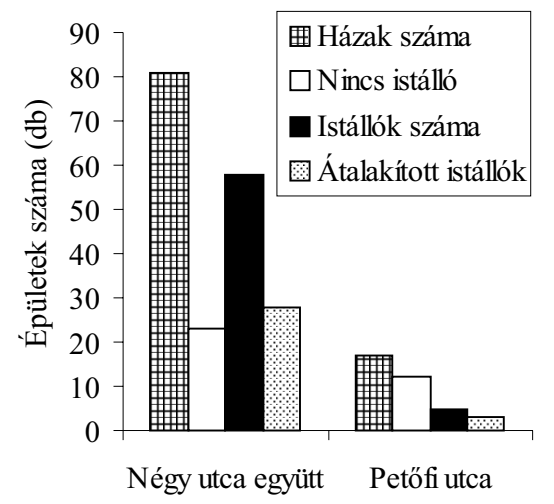

2. ábra. Kisgyalán lakóházainak, istállóinak, valamint az átalakítások utcánkénti száma (Négy utca: Árpád,

Kossuth, Dózsa utcák és Szabadság tér együtt)

Table 2: Numbers of the detached houses and sheds of Kisgyalán after the transformátion street by street

érdekessége, hogy egyazon udvarban az új házzal együtt két ház található. A régi vályogházat ugyanúgy lakják, így az új ház tulajdonképpen reprezentációs célokat szolgál a külvilág felé mutatva, hogy mód volt az elkészítésére. Itt a földes istállót elbontotta, az eredeti tulajdonos. Üresen álló házhelyen, a Táncsics utcában, Petőfi utcai tulajdonos, bontott anyagból épített házat, amely egyelöre üres, istálló itt nem épült. A 19 házból 7-hez tartozik istálló, ezekből 3-at alakítottak át szobává, fürdőszobává. Nem található istálló az udvarban, 11 esetben, (egy esetben, 1 udvarban, 2 ház). Új tulajdonosa van 11 háznak. Ezek közül 3-ban van istálló, ezeket alakították át.

A Kossuth utcában lévő 26 ház közül 13-hoz tartozik istálló, amelyek közül 3-at átalakítottak, ezek közül 1 szoba, 1 konyha, és egy fürdőszoba $3 \times 2$-es "lett levéve” az istállóból. Az istálló dísze itt is megmaradt. Ezek az istállók $40-30 \mathrm{~m}^{2}$ alapterületűek. 7-röl egyértelmüen megállapítható, hogy téglából készült. A fennmaradó 13 ház esetén nincs istálló, sajnos az új tulajdonosok nem tudták megmondani, hogy nem is volt, vagy lebontották, egy esetben kaptam válaszul, hogy lebontotta az eredeti tulajdonos. Azonban valószínűsíthető, hogy több istálló került elbontásra az utca 1921-óta történt megnyitása óta, de több is épült, mint a később nyitott utcákban.

A Petőfi utcában összesen 74 db lakóépület található. A falu gerincén elhelyezkedő, szubjektív szempontok szerint kiválasztott, átlagon felüli küllemü, és nagyságú gazdasági épületek száma 25 db. Ebböl 18 magyar, 7 német tulajdonosé. A fennmaradó 49 háznál 17-ben található átlagos szintü istálló. Nincs, illetőleg lebontották 32 esetben az istállót.

Kisgyalán Fonó szomszéd községe. „A községet nyugati végén két oldalt, a régi és az új temető, keleti végén a Hársasberki víztározó határolja. A templom a falu központi helyén található. Mögötte az 1900-ban épült magtár. Az 1710-as évek közepétől, a templomtól keletre terült el a falu. A templomtól fölfelé az 
1920-as Nagyatádi Szabó István féle földreform után építkeztek. Ekkor mérték ki a házhelyeket a mostani Kossuth utcában, ahol elötte kenderföldek voltak. Volt, aki a saját kenderföldjére építette a házát.

1946 után az uradalom istállóinak, cselédházainak bontási anyagából ${ }^{20}$ épültek fel a lakóházak a volt uradalomban dolgozók számára a Petőfi, illetve a Kossuth utca egy részén. A Petőfi utca köztudatban elterjedt neve Új utca, ami utalt új keletűségére, bár az azóta 60 év eltelte óta ez a név állandósult, mivel nem létesült azóta újabb utca. Az ekkor épült házak száma mutatja, hogy a gazdasági cselédek csaknem a felét tették ki a falu lakosainak.

A ma Kisgyalánban meglévő házak száma építési idejük szerinti csoportosításban: 1901-ben 1 ház, 1910 körül 4 ház, 1920 és 1946 között 31 ház, 1946 és 1960 között 32 ház, 1960 és 1980 között 25 ház, 1980 és 1990 között 3 ház, 1990 és 2000 között 3 ház, 2003ban 1 ház épült a faluban. Ezt követően felújítások, bővítések történtek."21

Az Árpád, Kossuth, Dózsa utca, Szabadság tér öszszesített adatai alapján a 81 ház közül, különálló az istálló 14 esetben, a ház vonalával folytatólagos $44 \mathrm{db}$. Nincs istálló 23 esetben, ebből lebontottak 14db-ot, nem építettek 7 házhoz egyáltalán istállót, és 2 dőlt össze. Az oka, hogy Kisgyalánban négy utca adatait együtt kezeljük, így hasonlíthatók a mintaszám alapján legjobban össze Fonó tősgyökeres lakóival, mivel Kisgyalánban is ezekben az utcákban élnek főként az első letelepülők utódai. Valamint szempont volt az is, hogy például a Dózsa utca csupán 4 házból állt, abból is a közelmúltban lebontottak egy házat, egy pedig erősen az összedőlés határán áll (100-2), így a kis mintaszám alapján, egyszerübb együtt kezelni a többi utcával. A falut elhagyó családok főként a volt gazdasági cselédekből kerültek $\mathrm{ki}$, abban az esetben is, ha Kisgyalánban építettek házat. Az 1946 után a volt gazdasági cselédek és a paraszt családok gyerekei között kötetett házasságokból alakult új családok továbbra is a faluban laknak. ${ }^{22}$

Ezekben az utcákban, magas az istállóból lakrészszé történt átalakítások száma, összesen 28 esetben történt meg. Fürdőszobát 7 , konyhát 5 , spájzot szintén 5 , szobát 3 , garázst, mühelyt 8 -at választottak le az istállókból. A legtöbb istálló cseréppel fedett, palával hetet fedtek be, ezek a tekintélyesebb korábban épült istállók közé tartoznak. A cserepeket legtöbb helyen az 1990-es években átforgatták, de történt teljes felújítás is. Földes padozatú istállóról egy esetben tettek említést. Arról többen megemlékeztek, hogy amióta nincsenek állatok, egyre kevesebb helyre jönnek meg a fecskék, bár a lehetőséget biztosítják számukra, nyitva hagyják a felső ajtót, és az ablakot. Azonban mivel

20 Bár e bontási anyagot főként a téglát illetően nem feltétlen házfal készült belöle, hanem csupán a ház alapja. Mivel ahhoz, hogy „el tudjanak indulni” a téglát el kellett adni, így nem egy esetben a ház fala már tömésfal.

21 Lanszkiné SZ. G. 2007: 124, 128

22 „A jelenlegi faluban Gyalán tösgyökeres lakosságából az eredet lakóhelyet 2007-ben 10 család birtokolja, illetve 7 ugyanott lakik, ahol ősei letelepedtek, illetöleg ezen családok leszármazottjai, 33-an új helyen élnek a községben."(Lanszkiné SZ.G. 2007: 17.) nincs állat, nincs légy az istállóban. Az istállók néhány esetet leszámítva hagyományos díszítésüek.

A hármasosztatú, három részből álló (egy tömör, és két fél) ajtók a leggyakoribbak. Állatot az 1990-es években tartottak a legtöbbjükben utoljára. Az állatállományra vonatkozó kérdésnél, akárcsak Fonóban, ironikus válaszok is elhangzottak. "Két kotlós van bent." „Az istálló eredeti állapotában van, tikoknak van bent lakásuk.” „Hátrafelé ment a jónép mikor nem tartott jószágot." A két szélsőérték a rendeltetésszerű használat megjelölésére 1972, és 2008 volt. Az 1980-as évek után épült házakhoz már nem épült istálló.

Kisgyalán Petőfi utcáját összehasonlítva Fonó azonos időpontban épült Dózsa utcájával, hasonló eredményt kapunk (1. - 2. ábra). A lakóházak száma itt 17 db, ebböl 1db- az 1990-es évek elején épült ház, itt volt üresen maradt házhely. Istálló 5 házhoz épült, ebből 3 esetben alakítottak szobává istállót. Az új tulajdonosok közül 5 német, illetve osztrák állampolgár, nyaralónak vásárolták az itteni ingatlant. Az 1949-es évek után a volt gazdasági cselédek leszármazottai közül négyen laknak ebben az utcában.

\section{A népi építészet emlékei}

Ez a jelen, de a múltból kell kiindulni, meg kell ismerni ezeknek az épületeknek az építésük, használatuk módját, milyen törekvések történnek megmentésükre. Az tapasztalható mindkét faluban, hogy ami szép azt nem hagyják veszni.

Fonóban még egy darab lakóház képviseli az igen távoli múltat (3. ábra), ez visszaemlékezések szerint, valószínűsíthető, hogy a 19. század végén épülhetett. A ház és a vele egybe épült istálló vályogból készült, több helyisége földes, köztük az istálló is. Mindezek ellenére, ma is tekintélyt sugároz, téglával kirakott pitarjának, és faragott oszlopainak köszönhetően (4. ábra).

Kisgyalánban úgyszintén, az 1920-as, 1940-es években, vagy ez előtt épült házak és az ehhez tartozó istállók egybeépültek, tetőgerinc magasságuk egyenlő magas.

„A lakó- és gazdasági épületek egybeépítése is gyakori volt a községrendezések után, szoba, konyha, kamra, istálló, pajta és fészer követte egymást. Ez a típus többnyire akkor keletkezett, mikor nagyjából egymás utáni években készült az összes épület. Erre vertfalú épületeknél is van példa, legtöbb emléke Külső-Somogyban."23

„Az istálló és a zsuppos házról készült fotón (1931) látható az egyik fő elv, amelyet a parasztság mindenekelőtt szeme előtt tartott. A modern, az akkori kor követelményeinek megfelelő terméskő alapon nyugvó cseréptetős istálló, a vele egybeépített fedett zárt pajtával, darálóval, ízléses boltíves építésével, kőcsipke díszítésével, milyen éles kontrasztban van az előtte meghúzódó kis fehérre meszelt alapokat nélkülöző alacsony, kevés kisablakú zsuppos házacskával." ${ }^{4}$ (5. ábra).

23 Knézy J. 1974: 58 .

24 Lanszkiné Sz. G. 2007: 128-129. 
„A 20. században a marhahús termelésére és a tejtermelésre szakosodott parasztgazdaságokban, különösen a Dunántúl németek lakta falvaiban hatalmas méretű istállókat építettek, melyek nagysága rendszerint a ház méretét is meghaladta. Az ilyen portákon gyakran az a furcsa helyzet állt elö, hogy az udvar tekintélyes részét elfoglaló, korszerű anyagokkal és szerkezetekkel épült istállók (és pajták) mellett szerényen húzódott meg a régi építési hagyományokat őrző lakóház." ${ }^{25}$ A magyar lakta falvakban is, erről tanúskodnak a fényképek.

Kisgyalánban az emeletes magtár (6. ábra), „1947ben épült optimista tervekkel a háború után. Az emelet a csöves kukorica számára készült góré módjára, a szellőzés megoldása érdekében léces oldallal. A magtár alapja terméskő, díszítése szemnek tetsző (...) Széles Istvánné portáján készült a kettős istállóról fénykép, mely tanúsítja a testvérek egy háztartásban való maradását, akik azonban a gazdálkodást külön-külön folytatták egy telken, az istálló ezért középen van elválasztva. Ez az istálló 1901-ben épült. Az eredeti palatető van rajta, ami mind máig nem ázik be, és még mindig szép. A szürke pala szabályos közönként piros palával van kombinálva, ez adja a díszítést"26 (7. ábra).

„Általánosnak tekinthető, hogy az öröklési rend, és az adott területnagyság miatt nem volt mód új telket foglalni az új családnak, hanem a portán adott egységeket többszörözték meg," ${ }^{27}$

Fonóban az országos hírnévre szert tett elődök, az 1920-as-40-es évek során építették fel irigylésre méltó gazdasági épületeiket. A szarvasmarha állomány alakulása gazdaságnagyság csoportok szerint is, ezt az istállóépítési törekvést igazolja. „A szarvasmarha állomány zöme a 100 kat. hold alatti üzemcsoportok tulajdonába volt és 1935-42 között e gazdaságok részesedése 73,3\%-ról, 83,3\%-ra emelkedett."28

Az átlag feletti minőségü gazdasági épületek száma jelenleg $25 \mathrm{db}$. ami a daráló istálló, pajta, együttesét jelenti, mindenesetben kelet-nyugati tájolásúak. Az épületek külcsínének megítélése szubjektív, így ez a szám növekedhet, vagy csökkenhet pár darabbal, az itt közölt fotók, a 25-ből kiragadottak (8. - 9. ábrák).

„A Délnyugat- Dunántúlon, Somogyban, Zalában, a Göcsejben és Örségben a pajtának nevezett csürök döntő többségükben háromosztatúak."29 Fonóban, Kisgyalánban a csür szó nem használatos, kizárólag a pajta szó az elterjedt. Az istállós pajta szóösszetétel helyett, egyszerüen istállót mondunk, ha az épületegyüttesről általánosságban beszélünk.

A gazdasági épületeket tulajdonosi szemszögből vizsgálva, arra a következtetésre jutottunk a házasságok számbavétele után, hogy ahol ezek az istállós pajták felépültek ott hat esetet leszámítva fonói leány, fonói legénnyel kötött házasságot. ${ }^{30}$ A fennmaradó 19

25 Balassa I. 1997: 216-217.

26 Lanszkiné Sz. G. 2007: 132-134.

27 Kottmayer T. 2003: 3-4.

28 Csöppüs I. 1975: 207

29 Balassa I. 1997: 216

30 Egy alkalommal nősült be lányos házhoz a Györ-Sopron megyéböl ide települt legény Wittmann Ferenc, akinek József nevű fia is az 1940-es években fonói lányt vett feleségül. Öt esetben, endogám házasság kötetett, falun belül léptek a házasság útjára a fiatalok.

Kisgyalánban, szintén szubjektív megítélés szerint 6 $\mathrm{db}$ átlagon felüli gazdasági épület található. Itt 3 esetben köttetett falun belüli házasság, 3 esetben pedig Fonó volt a kiszemelt célpont a tehetős családok számára. ${ }^{31} \mathrm{Ez}$ akárhogy is nézzük bizonyos fokú számítás, de a jólét alapját képezte. Azonos tehetségü családok sarjaiból lett egy pár. „A fiú hozta a gyusst (jusst), a lány pedig vitte.” $A$ juss tehát legtöbb esetben falun belül maradt. ${ }^{32}$ Sokszor kérdezés nélkül is szóba került, ki is finanszírozta az építkezést. „Vő volt náluk annak a gyussán építették.” A faluban, a közösségen belül, többnyire tudtak egymás anyagi helyzetéről. Vagy más esetben: „Apám építette az uram már csak vő volt.” „Menyecske vagyok, ennél a háznál." Ez a mondat különösen kedvesen csengett, mert a legtöbb segítséget nyújtó nyolcvan esztendős, szíves visszaemlékező szájából hangzott el 2011-ben.

A visszaemlékezések során mindig hangsúlyozták a fizikai munka keménységét, megerőltető voltát. „Korán hajnalban indultak el szegény apámék, tégláért Kaposba, hogy minél többet tudjanak egy nap fordulni. Sokat küszködtünk. Kettőt-hármat tudtak fordulni egy nap, 3-kor indultak hajnalban. 1938-ban kezdték épiteni, 1940-re készült el az istálló. 1942-ben, pedig 37 évesen, a Don kanyarban a több mint $-40 C^{\circ}$-os hidegben édesapám eltünt. '33 Teli reménnyel tettre készséggel építkeztek, a jövőre gondolva, de a sors közbe szólt. Arra is volt példa, hogy az I. világháborúban négy fiú testvér halt meg. „Ott maradt a sok tégla, a dolgos kezek oda vesztek, ezért a tervezett istálló helyett ház épült."

Istálló építésekor, szintúgy, mint ház építésekor bizonyos készültségi fok esetén: „Miután fölhúzták a falakat, még nem gyütt (jött) rá az épületfa, akkor került fel a falra a leveles ág krepp papírral díszítve, ami rózsaszín, zöld, piros volt, ki milyent vett." Így hirdetve az építkezés adott állapotát. „A falegyent mindenütt ünnepéllyel, az úgynevezett bokréta-ünnepéllyel szokták megülni, csakhogy mindenfelé másként. A kőművesek ugyanis csinos fenyő-, vagy nyírfa-, vagy akácfácskát szereznek,...amelyet aztán a napszámos lányok és menyecskék ízlésesen feldíszítenek." ${ }^{34}$ Bálizs Gyula építkezésének befejezéséről fotó is tanúskodik 1946-ból, éppen az ünnepélyes átadás, kézfogással megpecsételt pillanatát örökítette meg a fényképező az utókor számára (10. ábra). A következő képen látható a munkálatok befejezésének örömére tartott „á'domás” (áldomás), ahol a fehér asztalhoz, Somogy megye gazdasági felügyelője is hivatalos volt (11. ábra).

esetben Szentbalázsról, Kaposvárról, Mosdósról, Nagyberkiből, Kisgyalánból érkeztek az 1920-as, 40-as években a hasonló anyagi adottságú leányzók.

31 Egy esetben hoztak lányt, egyszer pedig vittek, vőnek is egy legény érkezett Kisgyalánba, aki megözvegyülése után újra Kisgyalánban nősült.

32 Az endogám házasságoknál vigyáztak, hogy rokon házasságok ne kötessenek. E családok leszármazottai között a szomszéd községekhez viszonyítva, sokkal magasabb a föiskolát, egyetemet végzettek aránya.

33 Szántó Imréné (Szabó Margit 1929) Fonó Petőfi u. 40. szíves közlése.

34 Richter M. 1942: 32 


\section{RENDELTETÉSÉNEK VÁLTOZÁSA}

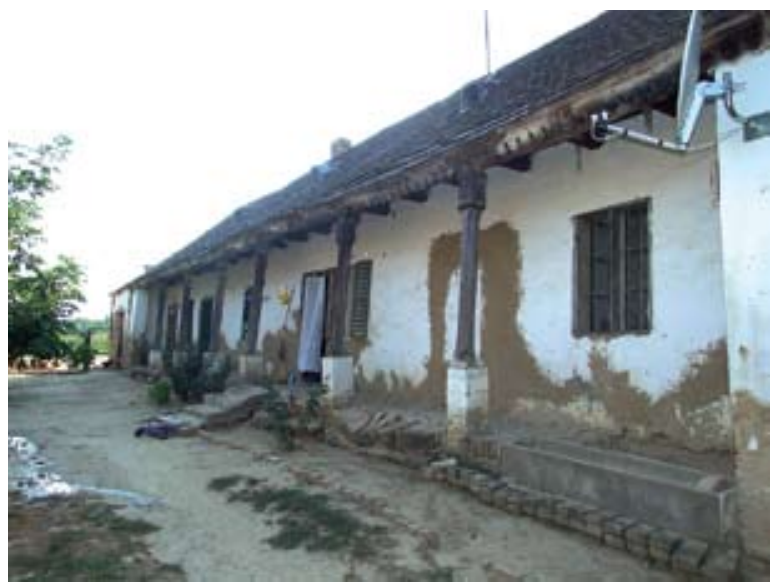

3. ábra. 19. sz. végi lakóház, istállóval (Fonó, Petőfi utca)

Figure 3: Detached house with a shed at the end of the19 th century (Fonó, Petöfi Street)

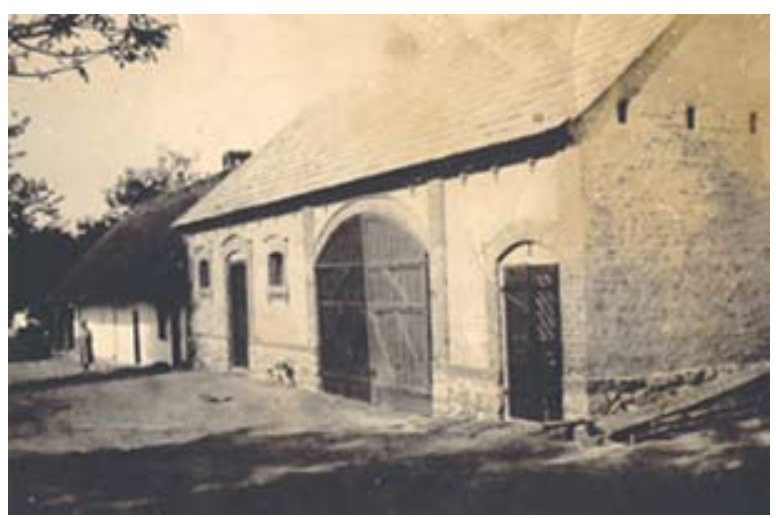

5. ábra. Istállós-pajta, és a zsúpos ház kontrasztja (Kisgyalán, Árpád utca)

Figure 5: Contrast of a thached house and a shed (Kisgyalán, Árpád Street)

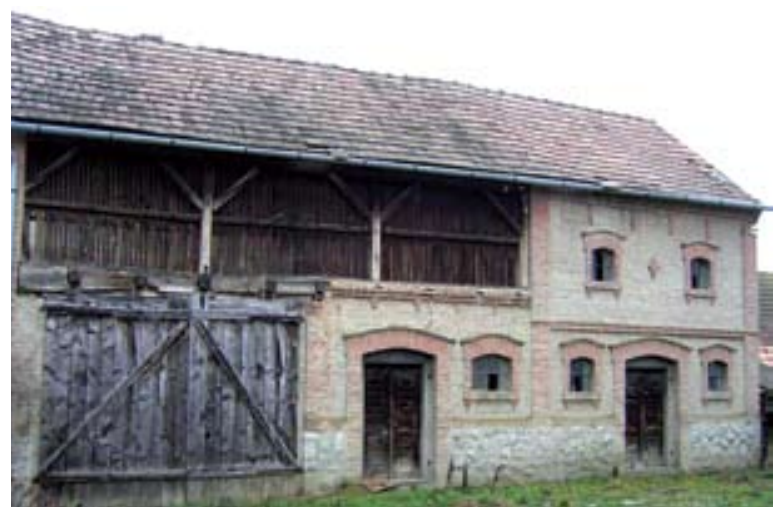

6. ábra. Emeletes magtár (Kisgyalán, Árpád utca) Figure 6: Multi-storey barn (Kisgyalán, Árpád Street)

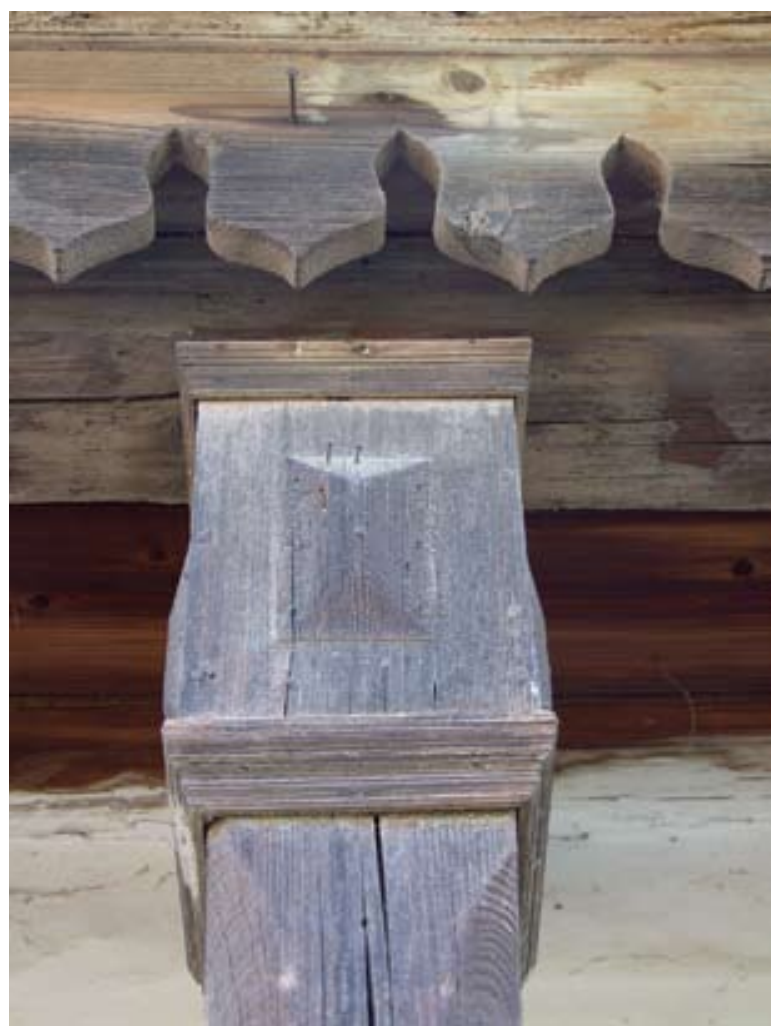

4. ábra. Faragott oszlop (Fonó, Petőfi utca)

Figure 4: Carved column (Fonó, Petöfi Street)

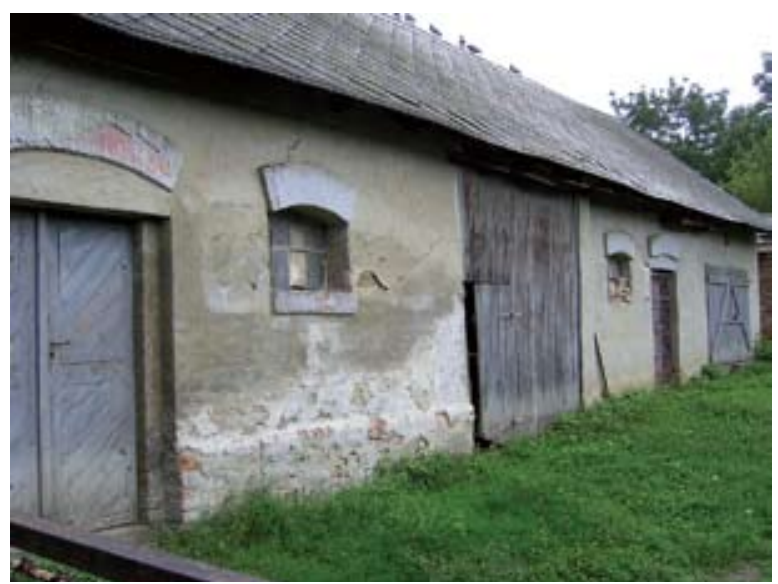

7. ábra. Kettős istálló (Kisgyalán, Árpád utca) Figure 7: Twinstable (Kisgyalán, Árpád Street) 

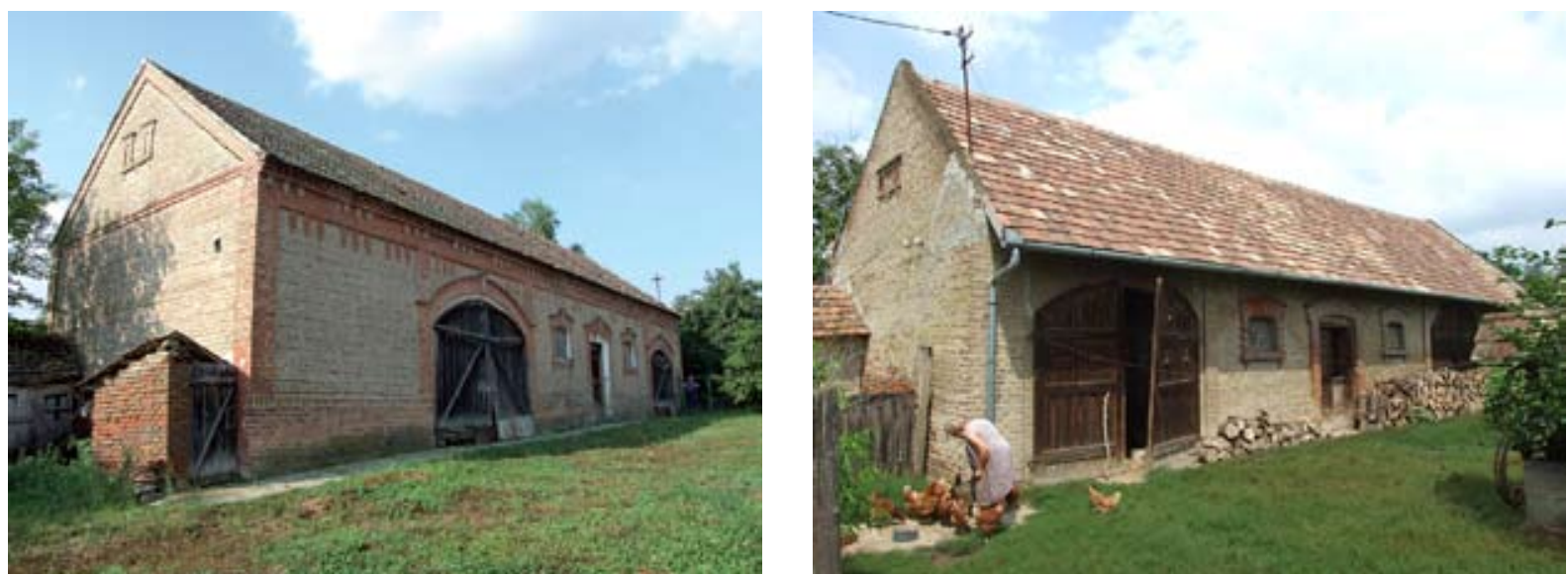

8.-9. ábra. Istállós-pajta (Fonó, Petőfi utca) Figure 8-9: Shed (Fonó, Petőfi Street)

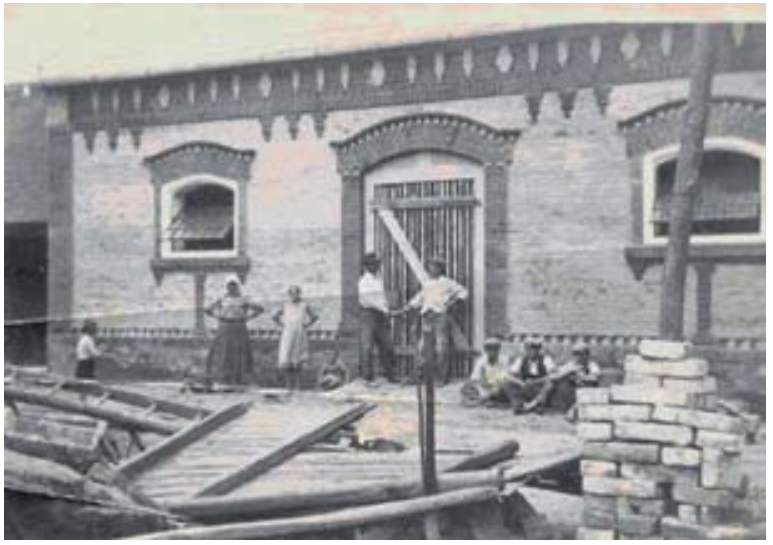

10. ábra. Az új istálló átadása (Fonó, Petőfi utca) Figure 10: Opening of a new shed (Fonó, Petőfi Street)

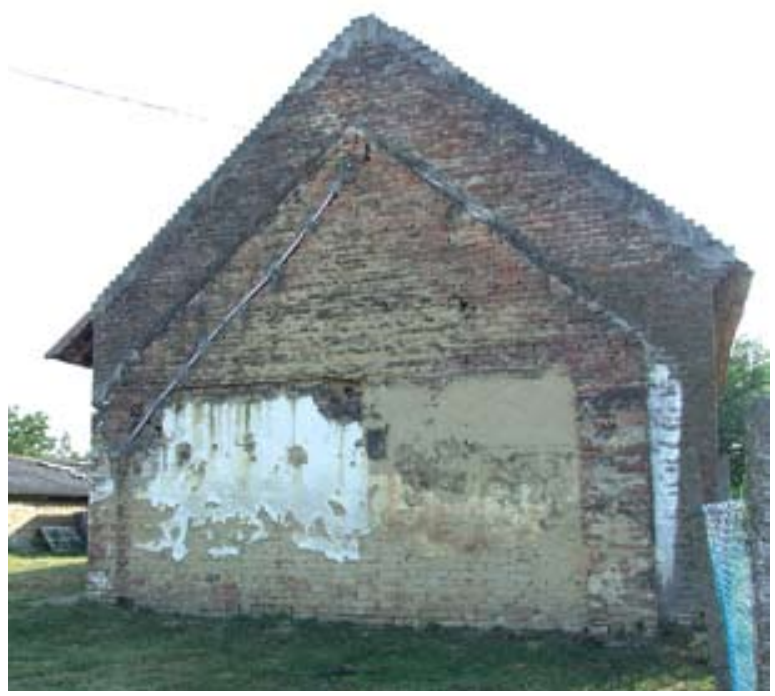

12. ábra. Istállón látható a lebontott ház sziluettje (Fonó, Petőfi utca)

Figure 12: The silhouette of the remains of a house on the shed's wall (Fonó, Petőfi Street)

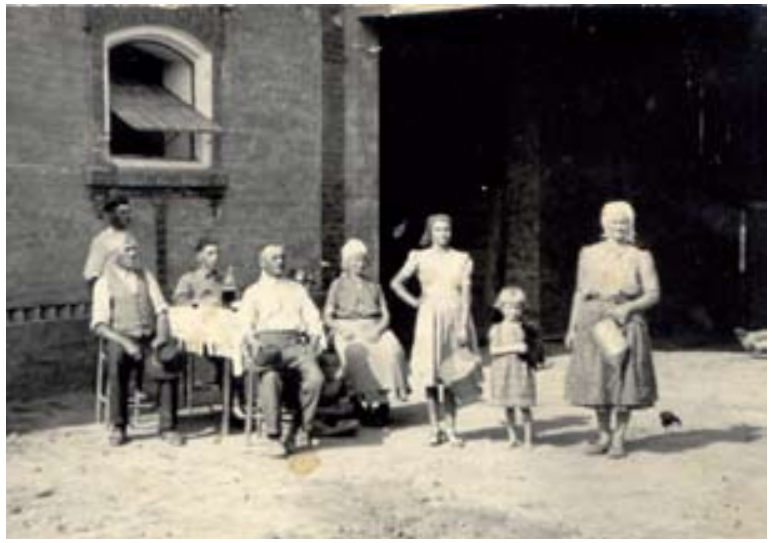

11. ábra. Az új istálló ünneplése (Fonó, Petőfi utca) Figure 11: Celebration of the new shed (Fonó, Petőfi Street)

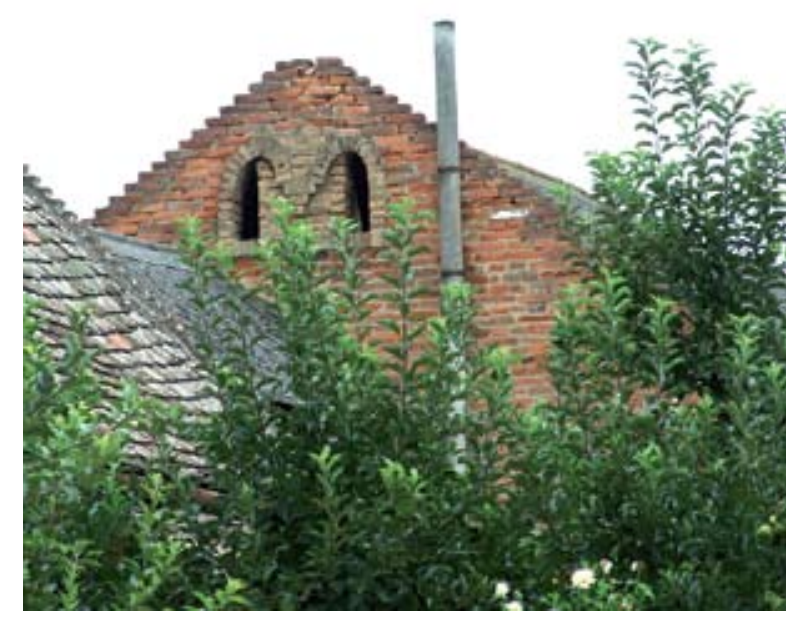

13. ábra. Istálló oromfal a kőmüves monogramjával (Fonó, Petőfi utca)

Figure 13: Gable of a stable with the builder's initials (Fonó, Petőfi Street) 


\section{RENDELTETÉSÉNEK VÁLTOZÁSA}

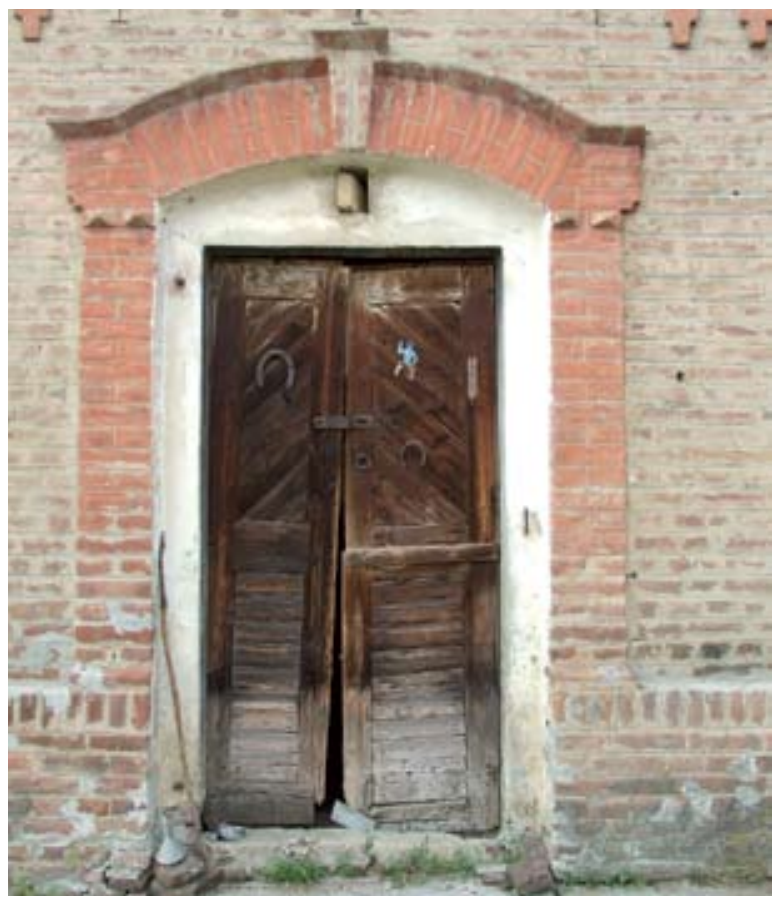

14. ábra. Hármasosztatú ajtó (Fonó, Petőfi utca)

Figure 14: Tripartite door (Fonó, Petőfi Street)

A gazdasági épület nagyobb rangot kapott, mint a ház ezt bizonyítja, hogy az istállók tetőgerinc magassága több esetben magasabb a házénál. A fotó, az istálló hangsúlyozott szerepét bizonyítja, a lebontott ház tetőszerkezetének nyomai, jól láthatóak a gazdasági épület csúcsfalán (12. ábra).

„A téglaistálló fontos dísze volt az udvarnak (...) a téglafalú istállókon díszes ablakkiképzés és olykor az építőmester monogramja is megtalálható" 35 (13. ábra). A monogramos oromfal, Fonóban az egyik legrégebben épült istállón látható, a visszaemlékező megemlítette, hogy „Apám zokon is vette, hogy a kőmüves saját monogramját örökítette meg." ${ }^{36}$ A többi istálló oromfalán nem monogramot láthatunk. A díszítések egyaránt igényesek, a tégla és a fa építészeti elemeken egyaránt, mindkét községben. A nyerstégla térbeli gazdag díszítettsége, ékelése a tetőszerkezet alatt, esetenként az oldalfalakon, az ablak, és az ajtó körül szinte minden esetben jellemző (14. - 15. ábra).

A tégladíszeket a csúcsfalon, igyekezett mindenki más-más módon alkalmazni. A legtöbbször ezek szimmetrikus, dupla díszek (16. - 17. ábrák). A pajta ajtók nagy méretüknél fogva szinte kívánták a díszítést. Különböző faragások, fából rátétes csillag díszek tették hangulatossá az épületet. A díszek egy esetben sem egyformák, de ennek ellenére az egyöntetüség benyomását keltik a szemlélőben. Tanúskodnak a készítésük során, az aprólékos munkára is kiterjedő igényességre, ami bizonyítja, hogy tulajdonosaik nem a múlandóság számára építkeztek.

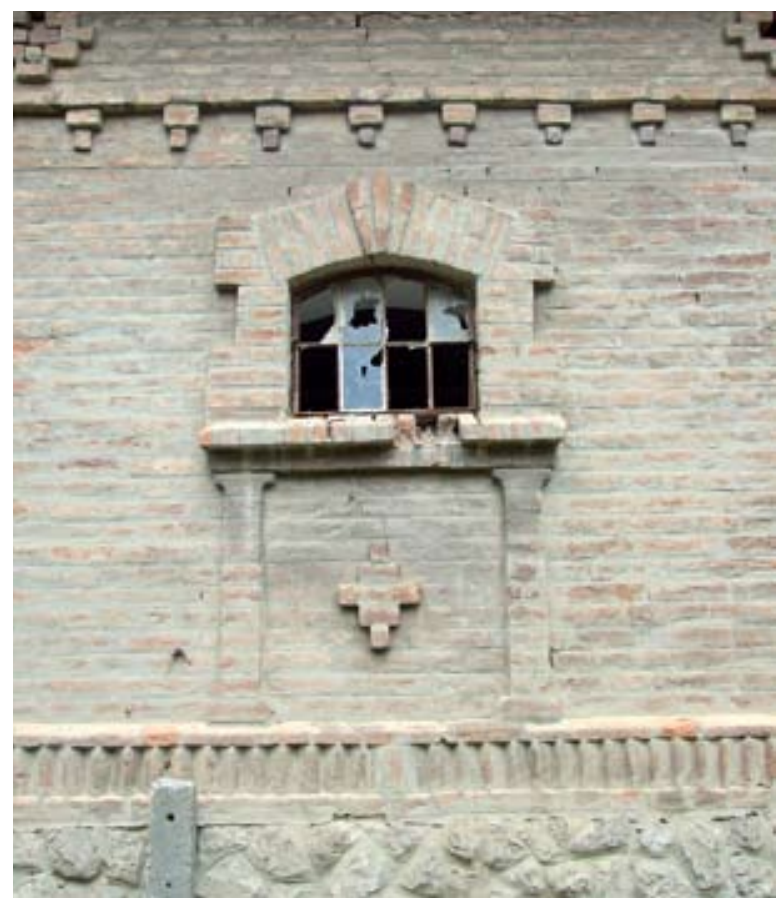

15. ábra. Ablak díszités (Fonó, Petőfi utca)

Figure 15: Window decoration (Fonó, Petőfi Street)

\section{A népi építészeti alkotások megmentésére tett törekvések}

Fonóban és Kisgyalánban egyaránt vannak példák az istálló teljes funkció váltására. Van ahol az épületeket teljesen eredeti állapotukban hagyták meg, kívülröl azonban bevakolták őket. A tulajdonosok mindkét esetben hagyománytisztelőek voltak, megörizték a kidomborodó díszeket, amit azáltal is hangsúlyozni kívántak, hogy azonos színnel, de más-más színárnyalattal festették be ezeket az épületelemeket. Kisgyalánban a holland tulajdonos billiárd szobát létesített a majd 100 $\mathrm{m}^{2}$-es istállóból. A jelenleg rózsaszín „ex” istálló színe ugyan kicsit meghökkentő a magyar szemnek, de a megőrzésen van a hangsúly a közösség számára is. „Ez olykor groteszk látványt eredményez, de jó esetben is csak gesztus értékü." ${ }^{37}$ A felújítások közt olyan esetre is van példa, hogy a tönkrement eredeti tégladíszítést állították vissza, a kőmüvesek is kedvteléssel végezték a nekik is tetsző feladatot.

A két község gazdaságtörténeti múltja eltérő, az istállók rendeltetésszerü használat változása közti példákban azonban fordított is adódik. Kisgyalánban a kevesebb számú nagy alapterületű istállóból, illetve magtárból is történt átalakítás. Fonóban a 25 darab istállós pajta változatlanul, eredeti funkciójának megfelelően várja további sorsának alakulását.

Kisgyalánban a község központi helyén található magtár kapott lakófunkciót, panzióvá alakítatta át a hol- 

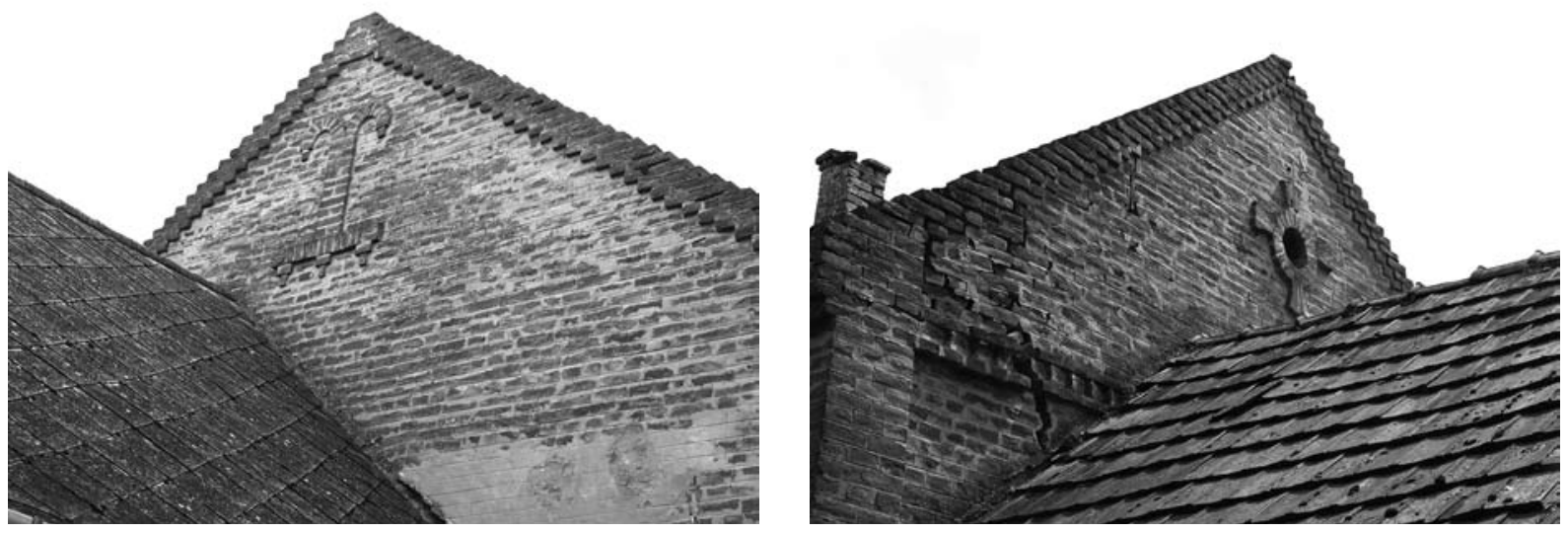

16.-17. ábra. Oromdísz (Fonó, Petőfi utca)

Figure 16-17: Gable decoration (Fonó, Petőfi Street)

land tulajdonos. ${ }^{38} \mathrm{Az} 1900$-ban magtár uradalmi épületnek épült, ezért a lebontás szele megérintette, amikor a II. világháborút követően a volt gazdasági cselédek számára az uradalom gazdasági épületei lebontásra kerültek. A kisgyaláni gazdák szépen megfogalmazott levelet írtak a magtár érdekében, amely levél ma a Nagyberki Levéltárban található. A levélben az a kérelem olvasható, hogy a gazdaközönség számára a magtárra szükség van, más épületeket bontsanak le lakóépület építése céljára. Kicsit több mint félévszázad elteltével, bontás nélkül a magtár maga vált lakóépületté.

38 Az átalakítás után szívélyesen meginvitálták a helybélieket, hogy belülröl is megszemlélhessék a változást. Az 1950-es években is még ennek a magtárnak a második emeletére csalánzsákban kellett felhordani a gabonát, ez jó fizikai erőnlétet igényelt, ami múltidézéskor többször is szóba kerül.

\section{Következtetések}

Az esztétikai élményt adó épületek megőrzésében mindkét község egyaránt jeleskedik. Ma is fontos szempont az átlagember számára is, legyen az góré, vagy egy gyönyörü istállós pajta, hogyha mód nyílik rá felújítják, vagy legalábbis eredeti díszítését megőrzik ezen épületeknek, építményeknek. Az azonban természetes, hogy a gyengébb minőségü tömésistállók lebontásra kerültek. Fonóban, ahol a komplex gazdasági épületek találhatóak, kevesebb a góré. A nagyobb tároló kapacitás magába fogadta a csöves kukorica mennyiségét is, itt ezért az istállós pajták megörzése a cél. Kisgyalánban viszont főként a tetszetős léces górék őrzik a múltat. Mindkét község jelenlegi arculata, még tükrözi múltbéli szerepét, ez teszi egyedivé a településképüket.

\section{Irodalom}

BALASSA I. 1997: Magyar néprajz. Életmód IV. Akadémiai Kiadó, Budapest. BENCZE G. 1975: Török Ferenc, Somogy megye mérnöke (1779-1832). - In: Kanyar J. (Szerk.), Somogy megye múltjából. Somogy Megyei Levéltár, Kaposvár, 6: 81-94.

Bocsor G. 1960: A magyar tarka marha. Akadémiai Kiadó, Budapest. Csöppüs I. 1975: A szarvasmarha állomány alakulása Magyarországon a második világháború időszakában. (1938-1944). In: Takács I. (Szerk.), Magyar Mezőgazdasági Múzeum Közleményei, 1973-1974: 185-228.

ETTIG L. 1999: A magyar tarka szarvasmarha bonyhádi tájfajtája. Mezőgazdasági Szaktudás Kiadó, Budapest.

FÁY A., KÁDÁR L. és VeZÉnYı E. 1936: Olvasó és tankönyv a katholikus osztatlan elemi népiskolák V-VI: osztálya számára. A Szent István-Társulat Kiadása, Budapest.

KIRÁlY I. 1962: Fejezetek a somogy megyei szarvasmarha tenyésztés történetéböl (1848-1945). In: Kanyar J. (Szerk.), Somogyi Almanach, 7: 3-86.

KIRÁLY I. 2004: A Dél- Dunántúl mezőgazdasága és állattenyésztése (1848-1944). A Szerző kiadása, Kaposvár.

Kıss E. 1935: Alsó-Dunántúl mezőgazdasága. Nyomtatott „Kultúra” Könyvnyomda, Kaposvár.
KNÉZY J. 1974: Települési változások Belső-Somogyban a reformkor végétöl a 20. század elejéig. Etnográfia, LXXXV: 48-60.

KotTMAYER T. 2003: Népi építészet, népi építkezés. Egyetemi jegyzet. Széchenyi István Egyetem, Győr.

LANSZKINÉ Sz. G. 2007: Kisgyalán története és néprajza. Kisgyalán Községi Önkormányzat, Kaposvár.

Lóczy I. 1978: A Kapos folyó völgyének rövid tájtörténeti áttekintése és a táj körülhatárolásának problémái. - Somogyi Múzeumok Közleményei, 3: 347-353.

Magyar Statisztikai Közlemények. Új sorozat 99. 105. kötet.

MELHARD GY. 1906: A székesfejérvári őrkanonokság története. Veszprém.

RıCHTER M. I. 1942: Építkezési szokások a nagy épületek emelésénél. - Etnográfia, LIII: 28-37.

Rosta F. 1961: Fonó község története. Kézirat.

SML: XIII. 45. Gyulai Gál család iratai. A batéi és a fonói malom iratai. 1816-1849.

SzITA L. 1993: Somogy megyei nemzetiségek település története a XVIII-XIX. században. - In: Szili F. (Szerk.), Somogyi Almanach 52: 3-143.

Somogyi Újság 1939. 01. 01. Kaposvár 